[Agr. Biol. Chem., Vol. 26, No. 4, p. 218 220, 1962]

\title{
Degradation of Nucleic Acids and Related Compounds by Microbial Enzymes
}

\author{
Part XI. Presence of 3 -Nucleotidase in the Culture Filtrate of \\ Bacillus subtilis
}

By Seizi Igarasi and Atsushi Kakinuma

Research Laboratories, Takeda Chemical Industries, Ltd., Osaka

Received September 8, 1961

\begin{abstract}
The culture filtrate of Bacillus subtilis decomposed ribonucleic acid into adenosine and orthophosphate without passing through 5 '-adenylic acid. It hydrolyzed neither 2'- nor $5^{\prime}$-nucleotides but only $3^{\prime}$-nucleotides into nucleoside and orthophosphate, while the cell suspension hydrolyzed 2'-, 3'- and 5'-nucleotides non-specifically. Thus 3'-nucleotidase was proved to exist in the culture filtrate of Bacillus subtilis.
\end{abstract}

\section{INTRODUCTION}

In the previous paper ${ }^{1)}$, the author reported that the enzymes in the culture filtrate of Bacillus subtilis (IFO 3032) degraded ribonucleic acid (RNA) and that about $50 \%$ of adenosine residue of substrate RNA was converted into $5^{\prime}$-adenylic acid (5'-AMP). During prolonged hydrolysis of RNA $5^{\prime}$-nucleotides that had been formed did not decrease while orthophosphate increased. Orthophosphate formation did not decrease by the addition of arsenate, an inhibitor of phosphatases. From those facts it was presumed that by the culture filtrate of Bacillus subtilis RNA was converted into 5'-nucleotides and into other intermediates which were hydrolyzed into adenosine (nucleosides) and orthophosphate with arsenate-resistant phosphatase.

Nishimura et al.2) have reported that ribo-

\footnotetext{
1) A. Kakinuma, S. Igarasi and K. Ogata, This Journal, 26, 213 (1962).

2) S. Nishimura and M. Nomura, Biochem. Biophys. Acta, 30, 430 (1958); S. Nishimura and B. Maruo, Proc. 8th Symposium on Nucleic Acids (Oct. 1959).
}

nuclease in the culture filtrate of a strain of Bacillus subtilis hydrolyzed RNA into $3^{\prime}$ nucleotides. We presumed that RNA would be hydrolyzed by our enzyme system into nucleosides and orthophosphate through the same pathway, and tried to show the existence of 3'-nucleotidase.

\section{EXPERIMENTAL}

Materials. Yeast RNA was obtained from the Kirin Research Institute, 2'-, 3'-mixed AMP, GMP, CMP, and UMP from Nutritional Biochemicals Corporation. 5'-AMP, GMP, IMP, CMP, and UMP were supplied by Takeda Chemical Industries. 2'-AMP and 3'-AMP were prepared form 2'-, 3'-mixed AMP by the method of Reichard et al. ${ }^{3)}$ and both of these compounds were pure as judged by paper chromatography in Solvent $1^{4}$ (see below).

Strains. Bacillus subtilis (IFO 3032).

Culture. The medium containing soluble starch $3 \%$, polypeptone $0.5 \%$, corn steep liquor $3 \%$, calcium carbonate $0.3 \%$ was neutralized and sterilized at $120^{\circ} \mathrm{C}$ for 10 minutes. After inoculation the flasks were placed on a reciprocal shaker and were incubat.

3) P. Reichard. Y. Takenaka and H.S. Loring, J. Biol. Chem., 198, 4) C.E. Carter, J. Amer. Chem. Soc., 72, 1466 (1950). 
ed at $28^{\circ} \mathrm{C}$ for 45 hours.

\section{Analytical Methods.}

Assay of Orthophosphate. Orthophosphate liberated by enzymatic hydrolysis was determined by the method of Fiske and Subbarow ${ }^{5}$.

Paper Chromatography. Paper chromatography was carried out on Whatman No. 1 paper at room temperature by ascending method in the following solvent systems: Solvent $\left.1^{4}\right), 5 \%$ dibasic sodium phosphate-isoamyl alcohol and Solvent $2^{6)}, 85 \%$ saturated $(16 \%)$ ammonium bicarbonate. After drying the paper was placed over a light-sensitive paper and irradiated with an ultraviolet light source with a maximum at $257 \mathrm{~m} \mu$.

\section{RESULTS AND DISCUSSION}

1) Effects of the Culture Filtrate and the Cell Suspension on $2^{\prime}-, 3^{\prime}-$, and $5^{\prime}$-AMP.

The cells and the supernatant were separated by centrifugation at $18,500 \times \mathrm{g}$ for 20 minutes. The cells were washed three times with the same volume of distilled water, followed by resuspending in the same volume of distilled water, while the supernatant was clarified by filtering through a Seitz filter. The cell suspension and the Seitz filtrate were used as enzyme preparations.

Mixtures of $0.2 \mathrm{ml}$ of $0.5 \mathrm{M}$ Tris-maleate buffer ( $\mathrm{pH} 5.5$ or 8.0$), 0.1 \mathrm{ml}$ of $10 \mathrm{~mm}$ substrate (2'-, 3'-, 5'- or 2'-, 3'-mixed AMP), and $0.2 \mathrm{ml}$ of enzyme preparation were in-

\begin{tabular}{|c|c|c|c|c|c|}
\hline \multicolumn{6}{|c|}{$\begin{array}{c}\text { AMP ISOMERS BY THE CULTURE FILTRATE } \\
\text { AND THE CELL SUSPENSION OF } \\
\text { Bacillus subtilis }\end{array}$} \\
\hline $\mathrm{pH}$ & 5.5 & & & 8.0 & \\
\hline Substrate & $\begin{array}{c}2^{\prime}-, 3^{\prime}- \\
\text { mixed } \\
\text { AMP }\end{array}$ & $\begin{array}{c}5^{\prime}- \\
\text { AMP }\end{array}$ & $\begin{array}{c}2^{\prime}- \\
\text { AMP }\end{array}$ & $\begin{array}{c}3^{\prime}- \\
\text { AMP }\end{array}$ & $\begin{array}{c}5^{\prime}- \\
\text { AMP }\end{array}$ \\
\hline $\begin{array}{l}\text { yme prepn. } \\
\text { ure filtrate }\end{array}$ & $46 \%$ & $1 \%$ & $1 \%$ & $92 \%$ & $2 \%$ \\
\hline ll suspension & 14 & 21 & 91 & 97 & 85 \\
\hline
\end{tabular}

Mixtures of $0.2 \mathrm{ml}$ of $0.5 \mathrm{M}$ Tris-maleate buffer (pH 5.5 or 8.0 ), $0.1 \mathrm{ml}$ of $10 \mathrm{~mm}$ substrate, and $0.2 \mathrm{ml}$ of enzyme preparation (cell suspension or Seitz filtrate) were incubated at $37^{\circ} \mathrm{C}$ for 2 hours.

5) C.H. Fiske and Y. Subbarow, J. Biol. Chem., 66, 375 (1925). 6) G. Hems, Arch. Biochem. Biophys., 82, 485 (1959). cubated at $37^{\circ} \mathrm{C}$ for 2 hours. The rate of orthophosphate liberation is shown in Table I.

The phosphatase in cell suspension cleaved all (2'-, 3'-, and 5'-) AMP isomers, but that of culture filtrate cleaved 3'-AMP exclusively. Optimal pH of both phosphatase activities in the cell suspension and in the culture filtrate were within alkaline range.

2'-, 3'-Mixed AMP was hydrolyzed by the culture filtrate at $\mathrm{pH} 8.0$ and the hydrolysate was subjected to paper chromatography. As shown by Fig. 1, with the action of phosphatase, 3'-AMP disappeared and adenosine appeared, while 2'-AMP remained unchanged.

2) Effects of the Culture Filtrate on $5^{\prime}$ - and $2^{\prime}-, 3^{\prime}-$ Mixed Nucleotides.

5'- or 2'-, 3'-Mixed nucleotides of various kinds of base moiety were hydrolyzed at $\mathrm{pH}$ 8.0 with the culture filtrate as described in 1).

From the data in Table II, the specificity of the enzyme was independent of base moiety of nucleotides, but was dependent only upon the position of phosphate bond.

TABle II. The SPECIFICITY OF THE ENZyMe IN THE CULTURE FILTRATE OF Bacillus subtilis TO 5'- and 2'-, 3'-MIXED NUCLEOTIDES

$\begin{array}{lccc}\text { Substrate } & \begin{array}{c}\text { Pi for- } \\ \text { mation }\end{array} & \text { Substrate } & \begin{array}{c}\text { Pi for- } \\ \text { mation }\end{array} \\ \text { 5'-AMP } & 1 \% & 2^{\prime} \text {-, 3'-mixed AMP } & 59 \% \\ \text { 5'-GMP } & 2 & 2^{\prime} \text {-, 3'-mixed GMP } & 71 \\ \text { 5'-IMP } & 0 & & \\ \text { 5'-CMP } & 0 & 2^{\prime} \text {-, 3'-mixed CMP } & 63 \\ \text { 5'-UMP } & 0 & 2^{\prime} \text { '-, 3'-mixed UMP } & 94\end{array}$

Mixtures of $0.2 \mathrm{ml}$ of $0.5 \mathrm{M}$ Tris buffer $(\mathrm{pH} 8.0), 0.1 \mathrm{ml}$ of $10 \mathrm{mM}$ substrate, and $0.2 \mathrm{mI}$ of culture filtrate were incubated at $37^{\circ} \mathrm{C}$ for 2 hours.

The results obtained here indicate that the culture filtrate of Bacillus subtilis hydrolyzed 3 '-nucleotides into nucleosides and orthophosphate. In conclusion it is evident that a 3 'nucleotidase exists in the culture filtrate of Bacillus subtilis.

Acknowledgement. The authors are indebted to Dr. S. Kuwada, Dr. K. Satō, Dr. S. Tatsuoka, 

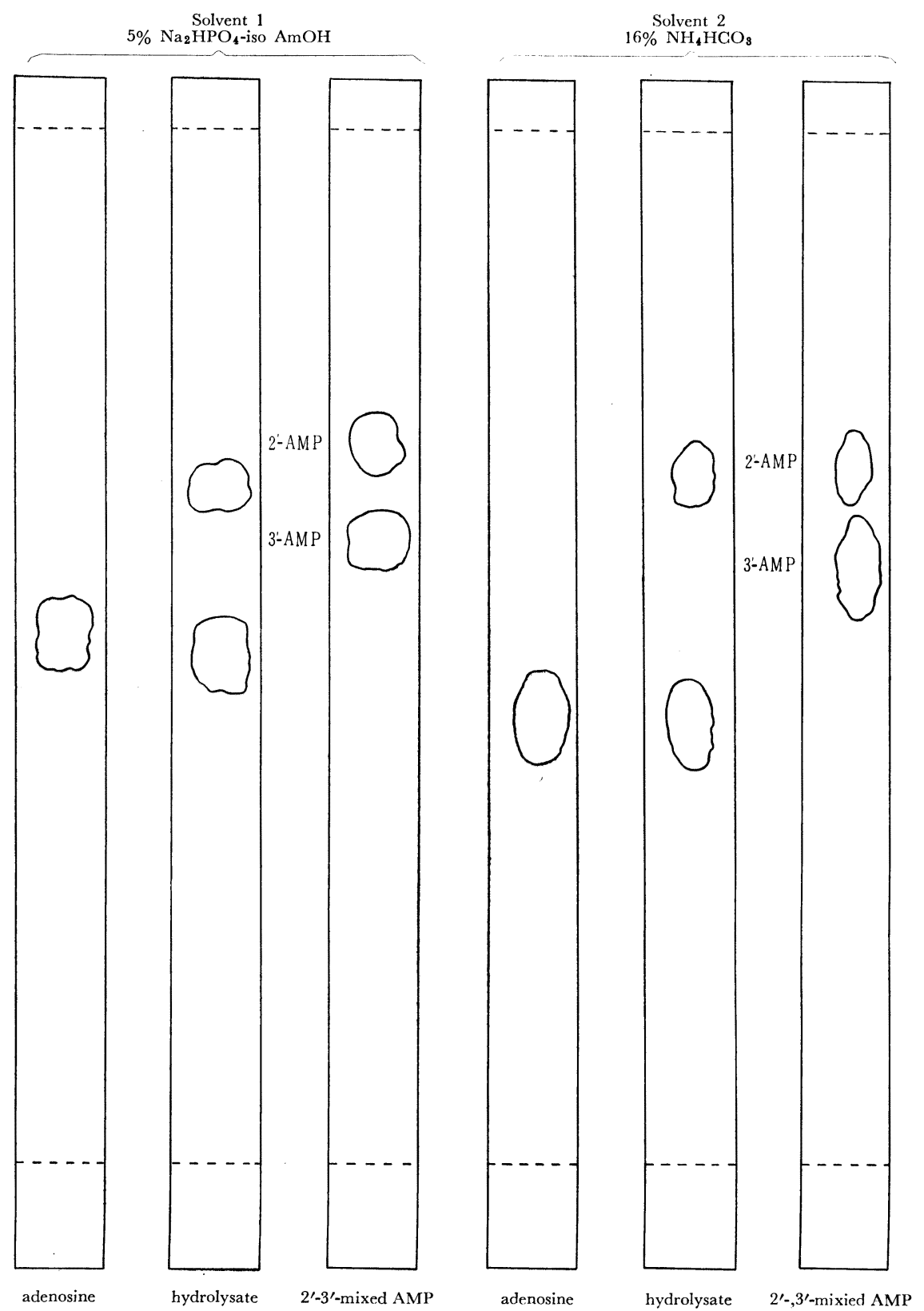

Fig. 1. Paper Chromatograms of Hydrolysates of 2'-,3'-Mixed AMP with the Culture Filtrate of Bacillus subtilis.

See Table II for the conditions of hydrolysis.

Dr. M. Abe and Dr. E. Omura of our laboratories and Prof. K. Ogata of Kyoto University

for their interests and encouragements during the course of this investigation. 